University of Nebraska - Lincoln

DigitalCommons@University of Nebraska - Lincoln

USDA National Wildlife Research Center - Staff Publications
U.S. Department of Agriculture: Animal and Plant Health Inspection Service

May 1998

\title{
Two Capture Techniques For American White Pelicans and Great Blue Herons
}

D. Tommy King

USDA/APHIS/WS National Wildlife Research Center, tommy.king@aphis.usda.gov

John D. Paulson

U.S. Department of Agriculture, Wildlife Service

Dwight J. LeBlanc

U.S. Department of Agriculture, Wildlife Service

Kevin Bruce

U.S. Department of Agriculture, Wildlife Service

Follow this and additional works at: https://digitalcommons.unl.edu/icwdm_usdanwrc

Part of the Environmental Sciences Commons

King, D. Tommy; Paulson, John D.; LeBlanc, Dwight J.; and Bruce, Kevin, "Two Capture Techniques For American White Pelicans and Great Blue Herons" (1998). USDA National Wildlife Research Center - Staff Publications. 553.

https://digitalcommons.unl.edu/icwdm_usdanwrc/553

This Article is brought to you for free and open access by the U.S. Department of Agriculture: Animal and Plant Health Inspection Service at DigitalCommons@University of Nebraska - Lincoln. It has been accepted for inclusion in USDA National Wildlife Research Center - Staff Publications by an authorized administrator of DigitalCommons@University of Nebraska - Lincoln. 


\title{
Two Capture Techniques For American White Pelicans and Great Blue Herons
}

\author{
D. TOMmY KING ${ }^{1,6}$, JOHN D. PAUlson ${ }^{2,4}$, Dwight J. LeBlanc ${ }^{3}$ AND KeVIN BrUCE ${ }^{2,5}$ \\ ${ }^{1}$ U. S. Department of Agriculture, National Wildlife Research Center, Mississippi Research Station, \\ P.O. Drawer 6099, Mississippi State University, Mississippi 39762, USA
}

${ }^{2}$ U.S. Department of Agriculture, Wildlife Services, P.O. Box 316, Stoneville, Mississippi 38776, USA

${ }^{3}$ U.S. Department of Agriculture, Wildlife Services, P.O. Box 589, Port Allen, Louisiana 70767, USA

${ }^{4}$ Present address: USDA/APHIS/WS, 2110 Miriam Circle, Suite A, Bismarck, ND 58504, USA

${ }^{5}$ Present address: USDA/APHIS/WS, 6213 Angus Dr., Raleigh, NC 27613, USA

${ }^{6}$ Internet: dtking@netdoor.com

\begin{abstract}
We describe two techniques for capturing American White Pelicans (Pelecanus erythrorhynchos), Great Blue Herons (Ardea herodias), and other large wading birds in aquatic habitats. One technique involved using \#3 padded jaw leghold traps modified by replacing both factory coil springs with weaker \#1.5 coil springs, to reduce the closing force of the jaws, and replacing the factory chain with a length of aircraft cable and an elastic shockcord, to minimize injury caused by lunging. The second technique involved using a modified portable rocket net that can be set in shallow water. We captured 142 American White Pelicans and 23 Great Blue Herons using these two techniques. We describe situations best suited for the optimum use of each technique. Both methods are humane and cost, labor, and time efficient. Received 15 January 1998, accepted 26 May 1998.
\end{abstract}

Key Words.-American White Pelican, Ardea herodias, leghold traps, Great Blue Heron, Pelecanus erythrorhynchos, rocket net.

Colonial Waterbirds $21(2):$ 258-260, 1998

A variety of bird species prey on commercially-raised fish at aquaculture farms in the southeastern United States (Fluery 1993; King 1997; Stickley and Andrews 1989). American White Pelicans (Pelecanus erythrorhynchos) and Great Blue Herons (Ardea herodias) can be locally common at such facilities. To determine the impact of these birds on the aquaculture industry and to develop more effective management strategies, we conduct a variety of studies with both captive and free-ranging birds. Some studies require capturing birds to collect biological data, attach markers or radio transmitters, or conduct enclosure tests on captive birds. However, we could find few methods in the literature about capturing pelicans and wading birds (Parris 1977; Simpson and Kelsall 1978). Here we describe two techniques that we used successfully to capture pelicans and herons.

\section{METHODS}

Leghold traps are most commonly used for capturing mammals, but padded leghold traps have been used to humanely capture raptors and ravens (Bloom 1987; J. Cummings and E. Knittle, pers. comm.; Harmata 1984; Hygnstrom and Craven 1994; Imler 1937). We modified padded leghold traps to capture pelicans and herons (Fig. 1). Both factory coil springs of Victor \#3 Softcatch (use of trade names does not imply government endorsement) traps were replaced with weaker Victor \#1.5 Softcatch coil springs. This lessens the initial impact of the padded jaws but still retains enough tension to hold the birds. The factory chain was replaced with a $20-\mathrm{cm}$ length of $3.7-\mathrm{mm}$ aircraft cable and a $30-\mathrm{cm}$ elastic shock-cord to minimize injury to captured birds.

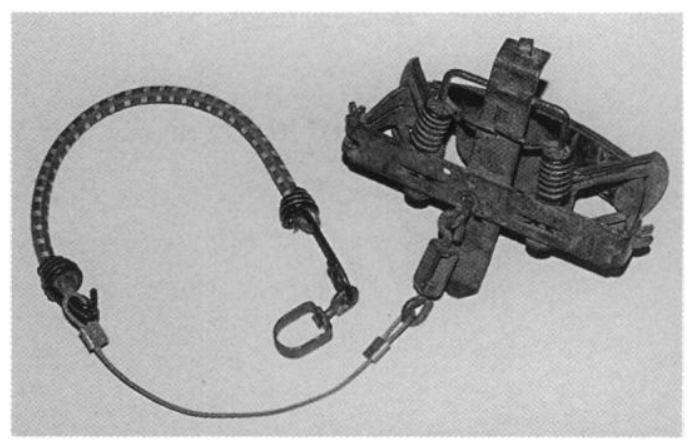

Figure 1. Modified Victor \# 3 Softcatch leghold trap showing trap springs, swivels, aircraft cable, and elastic shock-cord. 
Additional box and stake swivels were attached to increase the flexibility of the swivelling system.

We set modified leghold traps in areas of high bird densities, typically flooded fields for pelicans and catfish pond levees for herons. For pelicans, we slowly approached potential capture sites, flushed the birds, and set traps 3-4 $\mathrm{m}$ apart along transects. Traps set in the water were completely submerged but in water shallow enough that birds could step into them. Trap stakes were driven flush with the substrate, and the elasticshock cords and swivels were pushed into the mud or covered with sediment for concealment. For herons, traps were set both on dry land and along the water's edge $\leq$ one $m$ from the bank. Traps on levees were set using a basic dirt-hole set similar to that used for coyotes (Green et al. 1994). After setting traps we left the area for approximately one $h$. When returning, we attempted to drive the birds back to the capture site by walking or driving a vehicle toward them. We placed captured birds in $30 \times 30-\mathrm{cm}$ or $30 \times 50$-cm cloth bags and transported them on foot or by vehicle to another location.

We modified the portable rocket-net system described by Grubb $(1988,1991)$ by building the box out of three-mm aircraft aluminum (Fig. 2). We set the box, net, and rockets in water $2-4 \mathrm{~cm}$ deep with the box opening angled out of the water, on an exposed mud flat, or on a pond levee. We folded the net into the box prior to placing it at the capture site. We used $20 \times 10$-m or $15 \times$ 10 -m nets with three or two rockets, respectively. The net, stakes, and rockets were stored in the box and the entire device was easily transported by two people or by an ATV.

We used rocket-nets to capture American White Pelicans in south Louisiana and Chase Lake National Wildlife Refuge, North Dakota. In southern Louisiana we set the box on crawfish pond levees and mud flats where pelicans loafed. To habituate the pelicans to something new at their loafing site, we placed rectangular hay bales at the capture sites one-two $d$ before setting up the net. The hay bales were subsequently used to camouflage the boxes. At Chase Lake we set the box up on a sandy point that extended out from a peninsula and placed shrubby vegetation in front of the box for concealment.

\section{RESULTS}

We captured 24 American White Pelicans, 23 Great Blue Herons, two Great Egrets

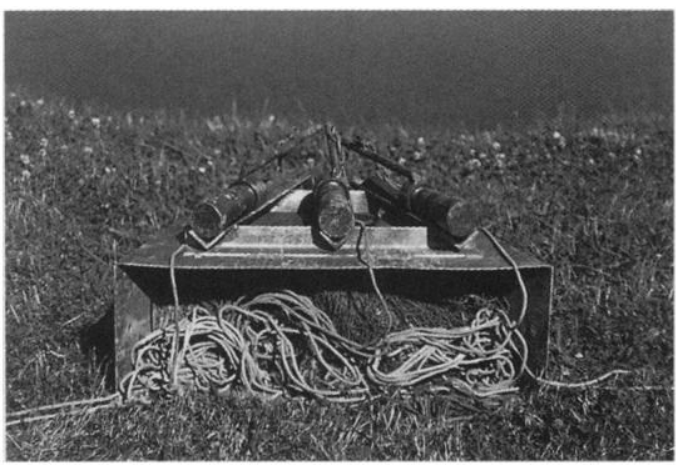

Figure 2. Modified portable rocket-net system showing the box, net, anchor lines and rockets.
(Ardea alba), one Yellow-crowned Night Heron (Nyctanassa violacea), one Roseate Spoonbill (Ajaia ajaja), and one Bonaparte's Gull (Larus philadelphia) with the modified leghold traps. No birds showed any apparent trap-related injuries other than a mild abrasion to a leg scale of one pelican. Transporting the traps from the vehicle to the capture site and setting them took approximately three man $h$ per 60 traps. Each modified trap cost approximately $\$ 14$

We captured 142 American White Pelicans during five firings of the modified portable rocket-nets. One pelican was struck by a rocket and died, and another was euthanized after a wing was broken by the leading edge of the net during the first capture. During subsequent captures, more care was taken to make sure the birds were not too close to the rocket-net box before firing. Equipment transport and setup time for each capture attempt was approximately 0.5 man $h$. The box, net and three rockets cost $\$ 940$ and each rocket charge cost $\$ 5$.

\section{Discussion}

Rocket-nets require less time and labor to set than do leghold traps but are not as efficient where birds are spread out or are wary of disturbance. In southern Louisiana, we used a rocket-net to capture as many as 40 pelicans that were loafing in a dense group of $<100$ birds. A disadvantage of rocket-nets is that after they are fired once, any uncaptured birds within $500 \mathrm{~m}$ leave the area. In the delta region of Mississippi, the pelicans we encountered were more wary, possibly due to infrequent human activity near the loafing sites. They quickly abandoned loafing sites where we placed camouflaged rocket-nets or left foot prints in the mud. The only success we had capturing pelicans in Mississippi was with modified leghold traps set under water. We never captured more than three pelicans per attempt with leghold traps.

The Great Blue Herons we encountered did not congregate in flocks dense enough to allow efficient use of rocket-nets. Individual catfish ponds often had more than $\mathbf{5 0}$ Great Blue Herons foraging or loafing along 
pond levees, but the birds usually maintained a spacing of several meters. Traps allowed us to sample a much larger area than would have been possible with rocket-nets. The prompt removal of herons from traps and transportation to another location resulted in minimal disturbance of other birds. We checked traps hourly and captured herons at the same site over a period of up to ten $h$.

The utility of the two capture techniques depends on the species, location and behavior of the birds to be captured. Both methods are humane and cost, labor, and time efficient. We believe that these techniques could also be used for capturing other species of wading birds.

\section{ACKNOWLEDGMENTS}

We thank D. Bergman, M. Brockman, T. Carpenter, B. Dorr, A. Gaude, G. Gaude, J. Glahn, N. Gleason, R. Greenwood, A. Grewe, G. Harper, B. Harrel, L. James, J. Kiesling, G. Knutsen, K. Kruse, G. Linz, P. Mastrangelo, D. Mott, J. Orth, R. Paciorek, D. Reinhold, D. Ruid, C. Sloan, P. Smith, M. Sovada, J. Suckow, M. Tobin, B. Vermillion, J. Wendel, A. Wilson, and the personnel of Clearwater Cajun Fisheries and Williams Inc., Indigo Island for their assistance with pelican and wading bird capture and processing. We thank the land owners for providing access to their property. We also thank M. Tobin, J. Glahn, R. McLean and two anonymous reviewers for their helpful comments on earlier drafts of this manuscript.

\section{LITERATURE CITED}

Bloom, P. H. 1987. Capturing and handling raptors. Pages 99-124 in Raptor management techniques manual. (B. A. Giron Pendleton, B. A. Millsap, K. W. Cline, and D. M. Bird, Eds.) National Wildlife Federation, Washington, D.C.
Fluery, B. E. 1993. Population trends in Louisiana herons, egrets, and ibises from 1949 to 1989 . Page 35 in Management of fish eating birds on fish farms: a symposium. (J. V. Huner, Ed.) National Aquaculture Association and National Audubon Society, New Orleans, Louisiana. 5-6 January.

Green, J. S., F. R. Henderson and M. D. Collinge. 1994. Coyotes. Pages C 64-68. in Prevention and control of wildlife damage. (J. E. Hygnstrom, R. M. Timm, G. Larson, Eds.) University of Nebraska Cooperative Extension, USDA/APHIS/ADC, Great Plains Agriculture Council, Lincoln, NE.

Grubb, T. G. 1988. A portable rocket-net system for capturing wildlife. Research Note RM-484. U.S.D.A., Forest Service, Rocky Mountain Forest and Range Experiment Station, Ft. Collins, CO.

1991. Modifications of the portable rocket-net capture system to improve performance. Research Note RM-502. U.S.D.A., Forest Service, Rocky Mountain Forest and Range Experiment Station, Ft. Collins, CO.

Harmata, A. R. 1984. Bald eagles of the San Luis Valley, Colorado; their winter ecology and spring migration. Ph.D. Dissertation, Montana State University, Bozeman, MT.

Hygnstrom, S. E. and S. R. Craven. 1994. Hawks and owls. page E 57. in Prevention and control of wildlife damage. (J. E. Hygnstrom, R. M. Timm, G. Larson, Eds.). University of Nebraska Cooperative Extension. USDA/APHIS/ADC. Great Plains Agriculture Council, Lincoln, NE.

Imler, R. H. 1937. Methods of taking birds of prey for banding. Bird Banding 8: 156-161.

King, D. T. 1997. American white pelicans: the latest avian problem for catfish producers. Proceedings of the Eastern Wildlife Damage Management Conference $7: 31-35$.

Parris, R. W. 1977. A method for capturing adult great blue herons. Proceedings of Colonial Waterbird Group. Pages 163-165.

Simpson, K. and J. P. Kelsall. 1978. Capture and banding of adult great blue herons at Pender Harbour, British Columbia. Proceedings of Colonial Waterbird Group. Pages 71-78.

Stickley, A. R., Jr. and K. J. Andrews. 1989. Survey of Mississippi catfish farmers on means, effort, and costs to repel fish-eating birds form ponds. Proceedings of the Eastern Wildlife Damage Management Conference 4: 105-109. 